Archive for

Organic Chemistry

Arkivoc 2017, part v, 1-9

\title{
A new synthesis of pleraplysillin-1, a sponge metabolite, using Wittig olefination
}

\author{
Moumita Rakshit, ${ }^{\text {G Gandhi K. Kar, }}{ }^{\text {** }}$ and Manas Chakrabarty ${ }^{b}$ \\ a Department of Chemistry, Presidency University, 86/1 College Street, Kolkata 700073, India \\ ${ }^{b}$ Formerly, Department of Chemistry, Bose Institute, 92 A.P.C. Road, Kolkata 700009, India \\ Email: gandhi.chem@presiuniv.ac.in
}

Received 01-05-2017

Accepted 05-15-2017

Published on line $06-25-2017$

\section{Abstract}

A new synthesis of pleraplysillin-1, a sponge metabolite, has been accomplished using Wittig olefination of 2bromo-1-formyl-4,4-dimethylcyclohex-1-ene with an appropriate ylide. A generalized study on the Wittig olefination of several 2-bromo-1-formyl-1-cycloalkenes with the ylides generated in situ from 2-(3/2furyl)ethyltriphenylphosphonium bromides was also undertaken as a prerequisite. The described methodology is not the most efficient route to the desired isomer. However, it does offer a new route to molecules of type 1, with the advantages that it (i) is relatively simple, (ii) does not involve expensive or toxic organometallic reagents, and (iii) affords overall yields of the bromo analogues and the final diastereoisomeric mixtures, which are much better than those previously reported.
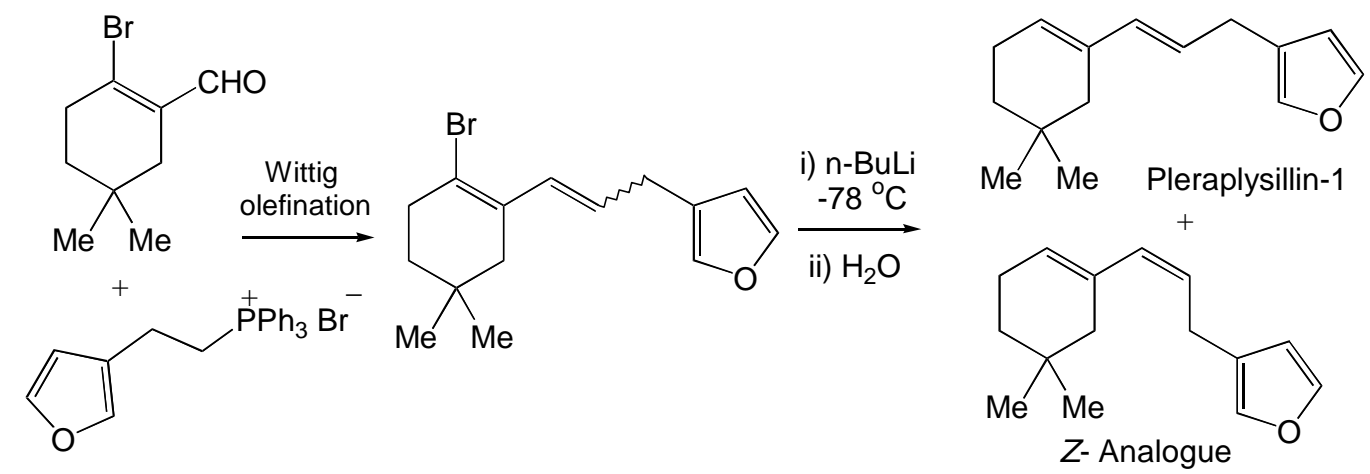

Keywords: Pleraplysillin-1, Marine natural products, Wittig olefination 


\section{Introduction}

In the recent past, we have been using $\beta$-halo- $\alpha, \beta$-unsaturated aldehydes as building blocks for the synthesis of various heterocycles, ${ }^{1-5}$ including furophenanthraquinones. ${ }^{6}$ In this context, our attention was recently drawn to pleraplysillin-1 (1), a cytotoxic furosesquiterpenoid isolated from Pleraplysilla spinifera, a marine sponge, by Cimino et al. ${ }^{7}$ It possesses a unique ochtodane, i.e., 3,3-dimethyl-1-ethylcyclohexane skeleton (2), ${ }^{8-10}$ (Figure 1) which is attached to a 3-furylmethyl group, and its 1,3-diene system is separated from the furan ring by a one-carbon unit.
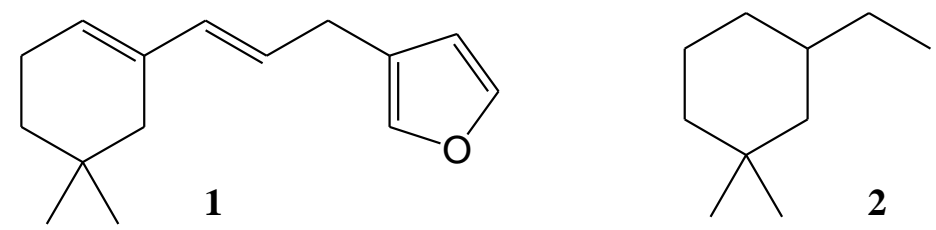

Figure 1. Pleraplysillin-1 (1) and ochtodane skeleton (2).

A decade later, its unique structure expectedly triggered its syntheses by Masaki et al. ${ }^{11,12}$ In the first synthesis that they reported, ${ }^{11}$ they synthesized 1 from an ochtodane monoterpenol using Sharpless regioselective epoxide ring-opening reaction as the crucial step. The final step was a reductive elimination of the $\beta$-acetoxy-sulfone which furnished a diastereomeric mixture of 1 with its Z-isomer in ca. 5:1 ratio (Scheme $1)$.

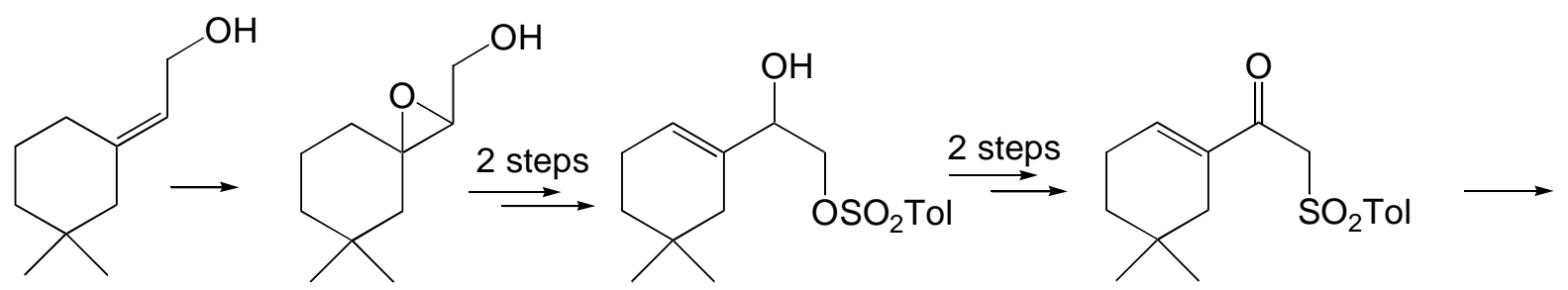

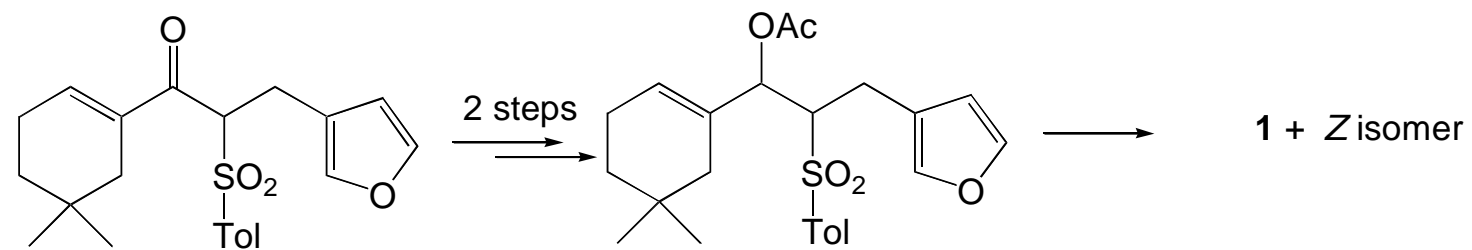

Scheme 1. First synthesis of pleraplysillin-1 (1) by Masaki et al. ${ }^{11}$

In their second report, ${ }^{12}$ they constructed the carbon skeleton of 1 by the coupling of a sulfone, derived from the same ochtodane monoterpenol, with 3-furylmethyl bromide, followed by successive detosylation, phenylthionation and elimination of thiophenol (Scheme 2). However, it furnished a regioisomeric mixture of 1 (major) and its $\Delta^{8,13}$-isomer (minor) in 3:2 ratio. In both reported syntheses, the overall yields were poor. 


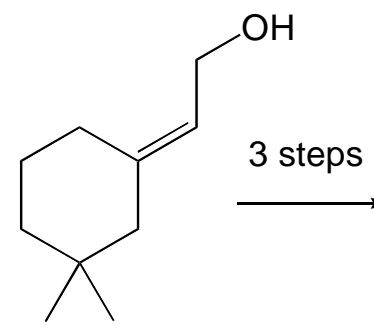<smiles>CC1(C)CCC/C(=C/[TeH])C1</smiles><smiles>C/C=C\C(=O)C(CCc1ccoc1)C1=CC(C)(C)CCC1</smiles>

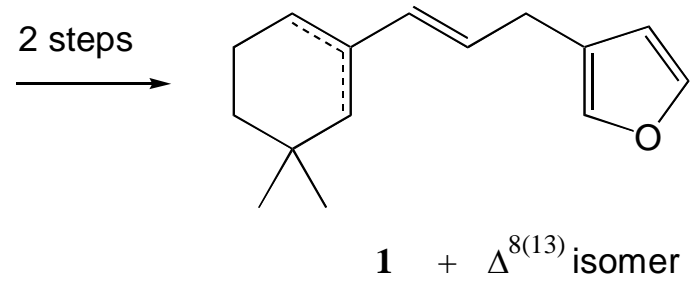

Scheme 2. Second synthesis of pleraplysillin-1(1) by Masaki et al. ${ }^{12}$

Scott et al. later reported an efficient synthesis of pure pleraplysillin-1 using $\mathrm{Pd}(0)$-catalyzed cross coupling of an (E)-furan-3-allyltin with 5,5-dimethylcyclohex-1-en-1-triflate. ${ }^{13,14}$ However, since in both of Masaki's attempts, the product was a mixture of regio- or stereo-isomers, we planned to utilize our ongoing strategy, viz. the employment of a suitable $\beta$-halo- $\alpha, \beta$-unsaturated aldehyde as a starting material for the development of a new synthesis of pleraplysillin-1 and its analogues via a new route using Wittig olefination as the crucial step. Our planned retro-synthesis of pleraplysillin-1 is depicted in Scheme 3.<smiles>CC1(C)CCC=C(/C=C/Cc2ccoc2)C1</smiles>

1

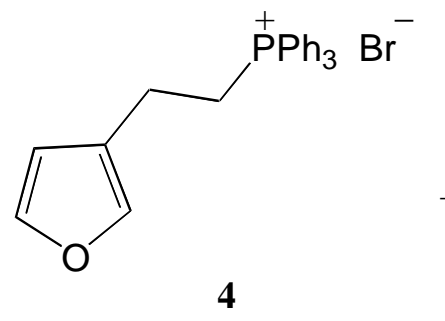

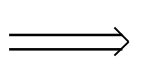

$+$

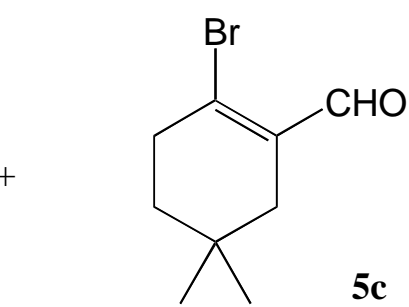<smiles>C=CC=CC1=C(Br)CCCC1</smiles>

3

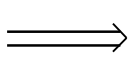<smiles>CC1(C)CCC(=O)CC1</smiles>

Scheme 3. Retrosynthesis of pleraplysillin-1 (1).

\section{Results and Discussion}

As shown above, pleraplysillin-1 can be synthesized by protodebromination of the corresponding bromo derivative 3 . The latter may be obtained by the Wittig olefination of the ylide [to be generated in situ from 2- 
(3-furyl)ethyltriphenylphosphonium bromide], 4) with 2-bromo-1-formyl-5,5-dimethylcyclohex-1-ene(5c). This plan necessitated a generalized study on the Wittig olefination of variously substituted 2-bromo-1-formylcycloalkenes (5a-e) with the ylides generated in situ from 3/2-furylethylphosphonium salts (4/6), in order to check the feasibility of our approach. The phosphonium salts were synthesized efficiently from 3/2furylethanol by successive $O$-tosylation $\left(\mathrm{TsCl}\right.$, pyridine), bromination ( $\mathrm{LiBr}, \mathrm{DMF}$ ) and phosphinylation ( $\mathrm{PPh}_{3}$ ). All but one (5c) of the 2-bromo-1-formylcycloalkenes had been prepared earlier by us from appropriately substituted cycloalkanones using modified Vilsmeier-Haack reaction. ${ }^{15,16}$ Compound $\mathbf{5 c}$ was prepared this time following a similar procedure.

The in situ generation of ylides from 4 and 6 and their reaction with 5a,e and 5a-e, respectively, was carried out in the presence of $n$-BuLi in THF at $-78{ }^{\circ} \mathrm{C}$ under argon atmosphere, which furnished diastereomeric $(E-+Z-)$ mixtures of the bromo analogues of the dienyl-3/2-furyl derivatives (7a,e/8a-e) in good overall yields (77-84 \%) (Scheme 4).

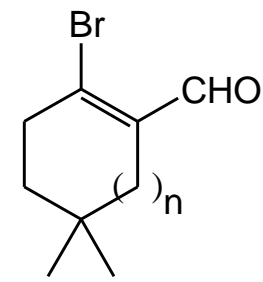

5

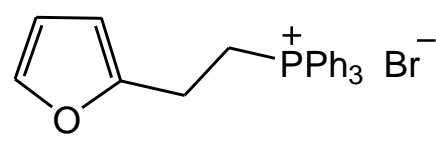

6

(i)<smiles>[R]C1([R])CCC(Br)=C(/C=C/Cc2ccoc2)C1</smiles>

$7 \mathbf{a}, \mathbf{e}+Z$-Isomers, $\quad E: Z=1:(1.8 / 1.7)$

$($ from $\mathbf{a}, \mathbf{e})$

(ii)<smiles>[R]C1([R])CCC(Br)=C(/C=C/Cc2ccco2)C1</smiles>

8a-e $+Z$-Isomers, $\quad E: Z=1:(1.6-2.3)$

(from a-e)

For $5,7, \mathbf{8} ; \mathbf{a}: \mathrm{n}=1 ; \mathrm{R}^{1}=\mathrm{R}^{2}=\mathrm{H} ; \mathbf{b}: \mathrm{n}=1 ; \mathrm{R}^{1}=\mathrm{H}, \mathrm{R}^{2}=M e ; \mathbf{c}: \mathrm{n}=1 ; \mathrm{R}^{1}=\mathrm{R}^{2}=M e$; d: $n=1 ; R^{1}=H, R^{2}=C_{3} ;$ e: $n=3 ; R^{1}=R^{2}=H$

Reagents and conditions: (i) 4, n-BuLi / THF, $-78^{\circ} \mathrm{C}$, Argon; (ii) 6, $n$-BuLi / THF, $-78^{\circ} \mathrm{C}$, Argon

Scheme 4. Wittig olefination of2-bromo-1-formyl-1-cycloalkenes (5a-e). 
Clearly, the desired diastereoselectivity was not achieved, and the E-/Z- ratios were found to be 1:1.6 to 1:2.3 (Table 1), as calculated from the relative intensities of the vinylic and the allylic proton signals in their ${ }^{1} \mathrm{H}$ NMR spectra. All of the products, with the exception of most of the bromo derivatives, were duly identified by ${ }^{1} \mathrm{H}$ and ${ }^{13} \mathrm{C}$ (PND) NMR spectra, supported by MS/analytical data.

Though lacking diastereoselectivity, the method offers a new route to the synthesis of molecules of type 1. We, therefore, applied this methodology to the synthesis of the bromo derivative of pleraplysillin-1. Thus, the ylide, generated in situ from 4, was allowed to react with the required bromo-formylcyclohexene (5c) under similar conditions. It furnished an inseparable (following silica-gel column chromatography) mixture of the desired (E)-isomer (3) and its (Z)-isomer in $88 \%$ overall yield (Scheme 5). The E-/Z- ratio, calculated as before, exhibited a greater lack of diastereoselectivity.

Table 1. Results of Wittig olefination of aldehydes 5a-e with phosphonium salts 4 and 6

\begin{tabular}{|c|c|c|c|c|c|}
\hline Entry & $\begin{array}{c}\text { 2-Bromo-1-formyl- } \\
\text { cyclohexenes }\end{array}$ & $\begin{array}{l}\text { Phosphonium } \\
\text { salt }\end{array}$ & $\begin{array}{c}\text { Products } \mathbf{7 / 8}+ \\
\text { Z-Isomer) }\end{array}$ & $\begin{array}{c}\text { Overall } \\
\text { yields (\%) }\end{array}$ & $\begin{array}{l}E-/ Z- \\
\text { ratio }\end{array}$ \\
\hline 1 & $5 a$ & 4 & $7 a+Z$-Isomer & 79 & $1: 1.8$ \\
\hline 2 & $5 a$ & 6 & $\mathbf{8 a}+$ Z-Isomer & 77 & $1: 1.6$ \\
\hline 3 & $5 b$ & 6 & $\mathbf{8 b}+$ Z-Isomer & 78 & $1: 2.3$ \\
\hline 4 & $5 c$ & 6 & $8 c+Z$-Isomer & 84 & $1: 2.3$ \\
\hline 5 & $5 d$ & 6 & $\mathbf{8 d}+$ Z-Isomer & 81 & $1: 1.6$ \\
\hline 6 & $5 e$ & 4 & 7e + Z-Isomer & 80 & $1: 1.7$ \\
\hline 7 & $5 e$ & 6 & $\mathbf{8 e}+$ Z-Isomer & 81 & $1: 1.6$ \\
\hline
\end{tabular}

Since the target molecule was formed, albeit as a diastereomeric mixture, its proto-debromination was accomplished by treating the mixture with $n$-BuLi/THF at $-78^{\circ} \mathrm{C}$ in THF under argon atmosphere for about $2 \mathrm{~h}$, followed by quenching with water. This reaction furnished a mixture of 1 and its Z-isomer in $77 \%$ overall yield (Scheme 5).

$$
\begin{array}{lll}
4+5 c & \text { i) } n \text {-BuLi/THF, }-78{ }^{\circ} \mathrm{C} \text {, Argon } \\
1: 78{ }^{\circ} \mathrm{C} \text {, Argon } & \text { ii) } \mathrm{H}_{2} \mathrm{O}
\end{array}
$$

Scheme 5. Synthesis of pleraplysillin-1 (1) and its Z-isomer. 


\section{Conclusions}

The present methodology to pleraplysillin-1 is certainly not the best of the available methods. It does, however, offer a new route to molecules of type 1 . Of course, conditions need to be developed to improve upon the diastereoselectivity at the crucial Wittig olefination stage. Our method has the additional advantages that (i) it is relatively simple, (ii) it does not involve expensive and toxic organometallic reagents and (iii) the overall yields of the bromo analogues and the final diastereomeric mixtures are much better than reported earlier.

\section{Experimental Section}

General. All the melting points were recorded in open glass capillaries in a sulfuric acid bath. The column chromatographies $(\mathrm{CC})$ were carried out in either silica gel $\left(\mathrm{SiO}_{2}\right)$ or neutral alumina $\left(\mathrm{Al}_{2} \mathrm{O}_{3}\right)$. For $\mathrm{CC}, \mathrm{SiO}_{2}$ and $\mathrm{Al}_{2} \mathrm{O}_{3}$ were purchased from E. Merck India and SRL, India. All of the reagents were of analytical grade and purchased from either Merck India or Sigma-Aldrich Chemicals. The $\beta$-bromo- $\alpha, \beta$-unsaturated aldehydes (5ae) were prepared from the respective cycloalkanones, procured commercially, using modified Vilsmeier-Haack reaction as was reported earlier from our laboratory. ${ }^{13,14}$ All the solvents were conventionally dried before use in reactions. Unless otherwise stated, the ${ }^{1} \mathrm{H}$ and ${ }^{13} \mathrm{C}$ (PND) NMR spectra were carried out in $\mathrm{CDCl}_{3}$ at $400 \mathrm{MHz}$ and $100 \mathrm{MHz}$, respectively.

General procedure for the synthesis of 2-(3/2-furyl)ethyltriphenylphosphonium salts (4/6). 2-(3-/2Furyl)ethylbromide $(0.35 \mathrm{~g}, 2 \mathrm{mmol})$ was stirred with solid $\mathrm{PPh}_{3}(1.31 \mathrm{~g}, 5.0 \mathrm{mmol})$ in a screw-cap reaction tube at $80^{\circ} \mathrm{C}$ for $12 \mathrm{~h}$. It was then stirred with dry ether $(20 \mathrm{~mL})$ for $30 \mathrm{~min}$. The solid separated was filtered off and washed thoroughly with dry ether and dried under vacuum to furnish the phosphonium salt which was stored in amber-colored bottle in a desiccator.

2-(3-Furyl)ethyltriphenylphosphonium bromide (4). White solid, yield $0.77 \mathrm{~g}(85 \%)$. m.p. $182-184{ }^{\circ} \mathrm{C} .{ }^{1} \mathrm{H}$ NMR:

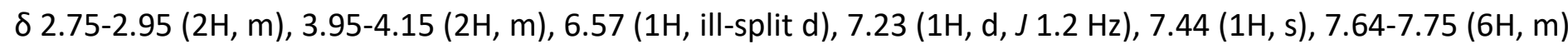
and 7.75-7.92 $(9 \mathrm{H}, \mathrm{m})$ ppm. ${ }^{13} \mathrm{C}$ NMR: $\delta 18.3,23.7,111.0,117.4,118.3,121.6,121.7,130.4,130.6,133.6$, 133.7, 135.1, 140.1, $143.1 \mathrm{ppm}$; ESI-MS(+): $\mathrm{m} / \mathrm{z} 437.3\left[\mathrm{M}+\mathrm{H} ; \mathrm{Br}^{79}\right]^{+}, 439.3\left[\mathrm{M}+\mathrm{H} ; \mathrm{Br}^{81}\right]^{+}$

2-(2-Furyl)ethyltriphenylphosphonium bromide (6). White solid, yield $0.70 \mathrm{~g} \mathrm{(78 \% ),} \mathrm{m.p.} 170-172{ }^{\circ} \mathrm{C} .{ }^{1} \mathrm{H}$ NMR: $\delta 3.19\left(2 \mathrm{H}, \mathrm{dt}, J_{1} 12.0 \mathrm{~Hz}, J_{2} 7.0 \mathrm{~Hz}\right), 4.19\left(2 \mathrm{H}, \mathrm{dt}, J_{1} 12.5 \mathrm{~Hz}, J_{2} 7.0 \mathrm{~Hz}\right), 6.15\left(1 \mathrm{H}\right.$, dd, further ill-split, $J_{1} 3 \mathrm{~Hz}, J_{2} 2$ $\mathrm{Hz}), 6.21(1 \mathrm{H}, \mathrm{d}, J 3.0 \mathrm{~Hz}), 7.09(1 \mathrm{H}, \mathrm{d}, J 2.0 \mathrm{~Hz}), 7.60-7.73$ and 7.77-7.90 (m each, $15 \mathrm{H}) \mathrm{ppm} .{ }^{13} \mathrm{C}$ NMR: $\delta 20.9$, 22.9, 107.6, 110.0, 130.1, 133.3, 134.6, 141.0, $150.1 \mathrm{ppm} ; \mathrm{ESI}-\mathrm{MS}(+): \mathrm{m} / \mathrm{z} 437.2\left[\mathrm{M}+\mathrm{H} ; \mathrm{Br}^{79}\right]^{+}, 439.3[\mathrm{M}+\mathrm{H}$; $\left.\mathrm{Br}^{81}\right]^{+}$

Synthesis of 2-bromo-1-formyl-5,5-dimethylcyclohex-1-ene (5c). $\mathrm{PBr}_{3}(0.6 \mathrm{~mL})$ was added dropwise to a solution of DMF $(0.9 \mathrm{~mL})$ and $\mathrm{CHCl}_{3}(2 \mathrm{~mL})$ at $0-5^{\circ} \mathrm{C}$. The ice bath was removed and the mixture stirred at $\mathrm{rt}$ for about $30 \mathrm{~min}$. It was again cooled to $0-5{ }^{\circ} \mathrm{C}$, a solution of 4,4-dimethylcyclohexanone $(0.25 \mathrm{~g}, 2 \mathrm{mmol})$ in $\mathrm{CHCl}_{3}$ $(1 \mathrm{~mL})$ was added dropwise to it, and the mixture was stirred at $\mathrm{rt}$ for another $8 \mathrm{~h}$ under anhydrous condition. The solution was poured into cold, saturated aq. $\mathrm{NaOAc}$ so that the $\mathrm{pH}$ was adjusted to $\sim 6$ and extracted with $\mathrm{CHCl}_{3}\left(3 \times 10 \mathrm{~mL}\right.$ ). The extracted organic layer was washed successively with water, aq. $\mathrm{NaHCO}_{3}$, again with water, dried and the solvent removed. The crude product was then purified by $\mathrm{CC}$ using PE as eluent, which furnished $5 \mathrm{c}$ as light yellow oil. Yield $0.33 \mathrm{~g}(76 \%)$. IR $\left(\mathrm{V}_{\max }, \mathrm{cm}^{-1}\right): 1695 .{ }^{1} \mathrm{H}$ NMR: $\delta 0.95(6 \mathrm{H}, \mathrm{s}), 1.53(2 \mathrm{H}, \mathrm{t}, J 6.5$ $\mathrm{Hz}), 2.08(2 \mathrm{H}, \mathrm{s}), 2.76(2 \mathrm{H}, \mathrm{t}, J 6.5 \mathrm{~Hz}), 10.03(1 \mathrm{H}, \mathrm{s}) \mathrm{ppm} .{ }^{13} \mathrm{C}$ NMR: $\delta$ 27.2, 28.0, 36.36, 36.38, 37.9, 133.6, 
142.2, 193.5 ppm. HR-ESI-MS(+): calcd for $\mathrm{C}_{9} \mathrm{H}_{13} \mathrm{O}^{79} \mathrm{Br} 216.015\left(\mathrm{M}^{+}\right)$and for $\mathrm{C}_{9} \mathrm{H}_{13} \mathrm{O}^{81} \mathrm{Br} 218.0129\left(\mathrm{M}^{+}\right)$, found $216.019 \& 219.012$.

General procedure for Wittig olefination; preparation of 7a,e; 8a-e. $n$-BuLi $(1.6 \mathrm{M}, 0.44 \mathrm{~mL}, 0.7 \mathrm{mmol}) \mathrm{was}$ added to a solution of the 2-(3-/2-furyl)ethylphosphonium salt(4/6) $(0.33 \mathrm{~g}, 0.75 \mathrm{mmol})$ in THF $(1 \mathrm{~mL})$ at $-78^{\circ} \mathrm{C}$ under argon atmosphere, and the solution was stirred for $30 \mathrm{~min}$ at that temperature. The solution of $5 \mathrm{a}-\mathrm{e}$ $(0.5 \mathrm{mmol})$ in THF $(1 \mathrm{~mL})$ was added slowly to the above mixture, and it was allowed to warm up to rt. Water $(0.5 \mathrm{~mL})$ was added to the mixture and THF evaporated off. The resulting aq. solution was extracted with ether $(3 \times 10 \mathrm{~mL})$, and the combined ether extracts were washed with cold water, dried and concentrated. The resulting crude product was purified by $\mathrm{CC}$ over $\mathrm{Al}_{2} \mathrm{O}_{3}$ to provide the furyl dienes as light yellow oil in the $\mathrm{PE}$ eluates.

(Since the bromo derivatives $7 \mathrm{a}, 7 \mathrm{e}, \mathbf{8 a}-\mathbf{e}$ were very unstable and we have no facilities to record MS and $\mathrm{C}, \mathrm{H}, \mathrm{N}$ analysis data in our University, we could not record the MS or elemental analyses data of these compounds.) (E)-3-[(2-Bromocyclohex-1-enyl)allyl]furan (7a) + Z-Isomer. Yield $0.105 \mathrm{~g}(79 \%) .{ }^{1} \mathrm{H}$ NMR: $\delta 1.69(4 \mathrm{H}, \mathrm{br} \mathrm{s})$, 1.91-2.11 (2H, m), 2.23-2.36 (2H, m), 3.24 and 3.29 (d each, J $7.5 \mathrm{~Hz}$ ) (total: $2 \mathrm{H}), 5.61\left(\mathrm{dt}, J_{1} 11.0 \mathrm{~Hz}, J_{2} 7.5 \mathrm{~Hz}\right.$ ) and $5.81\left(\mathrm{dt}, J_{1} 15.5 \mathrm{~Hz}, J_{2} 7.5 \mathrm{~Hz}\right.$ ) (total:1H), 6.11-6.19 (m) and $6.53(\mathrm{~d}, J=16.0 \mathrm{~Hz}$ ) (total: $2 \mathrm{H}), 7.11$ and $7.24(\mathrm{~s}$ each, further ill-split) (total: $2 \mathrm{H}$ ) ppm. ${ }^{13} \mathrm{C}$ NMR: $\delta$ 21.3, 21.5, 24.1, 24.6, 27.3, 27.5, 31.6, 31.9, 36.3, 37.4, 104.7, 105.4, 109.9, 110.2, 122.1, 123.6, 125.7, 125.9, 127.2, 131.8, 132.5, 133.2, 141.1, 141.9, 152.9, 153.4 ppm.

(E)-2-[(2-Bromocyclohex-1-enyl)allyl]furan (8a) + Z-Isomer. Yield $0.10 \mathrm{~g}(77 \%) .{ }^{1} \mathrm{H}$ NMR: $\delta 1.71$ (4H, br s), 2.20 2.31 and 2.53-2.66 (m each) (total: $4 \mathrm{H}), 3.44(\mathrm{~d}, J 7.5 \mathrm{~Hz}$ ) and 3.49 (d, J $6.5 \mathrm{~Hz}$ ) (total: $2 \mathrm{H}), 5.63$ (dt, $J_{1} 11.0 \mathrm{~Hz}$, $J_{2} 7.5 \mathrm{~Hz}$ ) and $5.84\left(\mathrm{dt}, J_{1} 15.5 \mathrm{~Hz}, J_{2} 7.5 \mathrm{~Hz}\right.$ ) (total: $\left.1 \mathrm{H}\right), 6.01-6.09(\mathrm{~m})$ and $6.73(\mathrm{~d}, J 16.0 \mathrm{~Hz})$ (total: $\left.2 \mathrm{H}\right), 6.26-$ $6.34(1 \mathrm{H}, \mathrm{m}), 7.29-7.36(1 \mathrm{H}, \mathrm{m})$ ppm. ${ }^{13} \mathrm{C}$ NMR: $\delta 21.7,21.9,24.2,24.3,27.1,27.8,31.2,31.5,36.1,37.1,104.8$, 105.1, 109.8, 109.9, 121.5, 123.5, 125.0, 125.8, 126.3, 131.2, 132.1, 132.9, 140.7, 140.9, 153.5, 153.7 ppm.

(E)-2-[(2-Bromo-5-methylcyclohex-1-enyl)allyl]furan (8b) + Z-Isomer. Yield 0.11 g (78\%). ${ }^{1} \mathrm{H}$ NMR: $\delta$ 0.95-1.03 $(3 \mathrm{H}, \mathrm{m}), 1.84-1.93(2 \mathrm{H}, \mathrm{m}), 2.23-2.31$ and 2.34-2.42 (m each) (total: $1 \mathrm{H}), 2.52-2.68(4 \mathrm{H}, \mathrm{m}), 3.44$ and 3.49 (d each, J 7.0/6.5 Hz) (total: $2 \mathrm{H}$ ), $5.63\left(\mathrm{dt}, J_{1} 11.0 \mathrm{~Hz}, J_{2} 7.5 \mathrm{~Hz}\right.$ ) and $5.85\left(\mathrm{dt}, J_{1} 15.0 \mathrm{~Hz}, J_{2} 7.0 \mathrm{~Hz}\right.$ ) (total: $1 \mathrm{H}$ ), $5.96-$ $6.08(\mathrm{~m})$ and $6.72(\mathrm{~d}, J 15.0 \mathrm{~Hz}$ ) (total: $2 \mathrm{H}), 6.26-6.34(1 \mathrm{H}, \mathrm{m}), 7.32$ and 7.33 (s each, further ill-split) (total: $1 \mathrm{H})$ ppm. ${ }^{13} \mathrm{C}$ NMR: $\delta$ 20.7, 21.0, 27.8, 28.3, 29.3, 31.5, 32.2, 32.4, 35.4, 36.1, 37.0, 39.4, 104.8, 105.1, 109.8, 110.7, $121.1,123.1,131.0,132.0,132.3,140.7,140.92,140.96,153.4,153.7$ ppm.

(E)-2-[2-Bromo-5,5-dimethylcyclohex-1-enyl)allyl]furan (8c) + Z-Isomer. Yield $0.124 \mathrm{~g}(84 \%) .{ }^{1} \mathrm{H}$ NMR: $\delta 0.90-$ 1.0 (overlapping s's) (total: $6 \mathrm{H}), 1.42-1.52(2 \mathrm{H}, \mathrm{m}), 2.01$ and 2.04 (s each) (total: $2 \mathrm{H}), 2.52-2.66(2 \mathrm{H}, \mathrm{m}), 3.41$ and 3.48 (d each, $J 7.5 / 7.0 \mathrm{~Hz}$ ) (total: $4 \mathrm{H}), 5.62\left(\mathrm{dt}, J_{1} 11.0 \mathrm{~Hz}, J_{2} 7.0 \mathrm{~Hz}\right.$ ) and $5.82\left(\mathrm{dt}, J_{1} 15.0 \mathrm{~Hz}, J_{2} 7.5 \mathrm{~Hz}\right)$ (total: $1 \mathrm{H}), 5.60(\mathrm{~d}, J 12.0 \mathrm{~Hz}$ ) and $6.72(\mathrm{~d}, J 15.0 \mathrm{~Hz})$ (total: $1 \mathrm{H}), 6.0-6.05$ and 6.26-32 (m each) (total: $2 \mathrm{H})$, 7.311 (s, further ill-split) and $7.33(\mathrm{~d}, J 1.0 \mathrm{~Hz}$ ) (total: $1 \mathrm{H})$ ppm. ${ }^{13} \mathrm{C}$ NMR: $\delta ~ 27.7,28.0,28.1,29.0,29.3,29.7$, 31.8 , 34.3, 35.2, 37.1, 41.1, 45.3, 105.2, 105.5, 110.2, 120.4, 126.1, 126.8, 131.6, 132.1, 132.6, 141.1, 141.3, $153.8,154.1 \mathrm{ppm}$.

(E)-2-[(2-Bromo-5-tbutylcyclohex-1-enyl)allyl]furan(8d)+ Z-Isomer. Yield $0.13 \mathrm{~g}(81 \%) .{ }^{1} \mathrm{H}$ NMR: $\delta$ 0.75-0.85 $(9 \mathrm{H}$, overlapping s's), 1.22-1.34 (2H, m), 1.67-1.79 (1H, m), 2.10-2.19, 2.26-2.36 and 2.45-2.61 (m each) (total: $4 \mathrm{H}), 3.37\left(\mathrm{~d}, J 7.5 \mathrm{~Hz}\right.$ ) and $3.42(\mathrm{~d}, J 6.5 \mathrm{~Hz}$ ) (total: $2 \mathrm{H}), 5.56\left(\mathrm{dt}, J_{1} 11.0 \mathrm{~Hz}, J_{2} 7.5 \mathrm{~Hz}\right.$ ) and $5.78\left(\mathrm{dt}, J_{1} 15.5 \mathrm{~Hz}, J_{2}\right.$ $7.0 \mathrm{~Hz}$ ) (total: $1 \mathrm{H}$ ), 5.92-6.0 (m) and $6.65(\mathrm{~d}, J 16.0 \mathrm{~Hz}$ ) (total: $2 \mathrm{H}$ ), 6.21 and 6.23 (quintet each, $J 1.5 \mathrm{~Hz}$ ) (total: $1 \mathrm{H}), 7.23$ (s, further ill-split) and $7.26(\mathrm{~d}, J 1.5 \mathrm{~Hz}$ ) (total: $1 \mathrm{H}) \mathrm{ppm} .{ }^{13} \mathrm{C}$ NMR: $\delta 25.6,26.7,26.8,27.8,28.7,29.9$, 31.5, 31.7, 31.9, 32.9, 37.2, 38.1, 43.2, 43.4, 104.8, 105.1, 120.9, 123.3, 125.6, 126.4, 131.0, 131.3, 132.3, $132.8,140.7,140.9,153.6,153.7$ ppm. 
(E)-3-[(2-Bromocyclooct-1-enyl)allyl]furan (7e) + Z-Isomer. Yield 0.117 g (80\%). ${ }^{1} \mathrm{H}$ NMR: $\delta$ 1.21-1.42 (8H, m), 2.08 and 2.19 (t each, J $6.0 \mathrm{~Hz}$ ) (total: $2 \mathrm{H}$ ), 2.14 and 2.18 (t each, J $6.0 \mathrm{~Hz}$ ) (total: $2 \mathrm{H}$ ), 3.22 and 3.31 (d each, J $7.5 \mathrm{~Hz}$ ) (total: $2 \mathrm{H}), 5.61\left(\mathrm{dt}, J_{1} 11.5 \mathrm{~Hz}, J_{2} 7.5 \mathrm{~Hz}\right.$ ) and $5.76\left(\mathrm{dt}, J_{1} 15.5 \mathrm{~Hz}, J_{2} 7.0 \mathrm{~Hz}\right)($ total: $1 \mathrm{H}), 6.06-6.13(\mathrm{~m})$ and $6.28(\mathrm{~d}, J 15.5 \mathrm{~Hz})$ (total; $2 \mathrm{H}), 7.11\left(1 \mathrm{H}, \mathrm{s}\right.$, further ill-split) and 7.23-7.25 (1H, overlapping d's) ppm. ${ }^{13} \mathrm{C}$ NMR: $\delta$ 25.7, 26.0, 26.2, 26.5, 27.31, 27.37, 28.0, 28.5, 29.1, 29.3, 31.4, 32.0, 37.1, 38.0, 104.9, 105.5, 123.3, 125.4, $126.0,126.8,131.5,132.4,134.6,135.7,141.0,141.3,154.0,154.1 \mathrm{ppm}$.

(E)-2-[(2-Bromocyclooct-1-enyl)allyl]furan (8e) + Z-Isomer. Yield $0.12 \mathrm{~g}(81 \%) .{ }^{1} \mathrm{H}$ NMR: $\delta$ 1.45-1.65 (6H, m), $1.69(2 \mathrm{H}$, quintet, $J 7.0 \mathrm{~Hz}$ ), 2.38 and 2.49 (t each, $J 6.0 \mathrm{~Hz}$ ) (total: $2 \mathrm{H}$ ), 2.74 and 2.79 (t each, J $6.0 \mathrm{~Hz}$ ) (total: $2 \mathrm{H}$ ), 3.44 and 3.50 (d each, $J 7.5 \mathrm{~Hz}$ ) (total: $2 \mathrm{H}$ ), $5.62\left(\mathrm{dt}, J_{1} 11.5 \mathrm{~Hz}, J_{2} 7.5 \mathrm{~Hz}\right.$ ) and $5.86\left(\mathrm{dt}, J_{1} 15.5 \mathrm{~Hz}, J_{2} 7.0 \mathrm{~Hz}\right.$ ) (total: $1 \mathrm{H}$ ), 5.98-6.06 (m), 6.27-6.33 (m), $6.65(\mathrm{~d}, \mathrm{~J} 15.5 \mathrm{~Hz}$ ) and 7.30-7.35 (overlapping d's) (total: $4 \mathrm{H})$ ppm. ${ }^{13} \mathrm{C}$ NMR: $\delta$ 26.1, 26.4, 26.5, 26.7, 28.1, 28.3, 28.6, 28.9, 29.4, 29.8, 32.0, 33.0, 37.5, 38.5, 105.3, 105.6, 123.7, $125.8,126.6,126.9,131.9,132.4,135.1,136.1,141.2,141.4,154.1,154.3$ ppm.

(E)-3-[(2-Bromo-5,5-dimethylcyclohex-1-enyl)allyl]furan (3) + Z-Isomer. Yield $0.13 \mathrm{~g}(88 \%) .{ }^{1} \mathrm{H}$ NMR: $\delta$ 0.91, 0.95, 0.96, 0.99 (overlapping s's) (total: 6H), 1.45-1.53 (2H, m), 2.01 (maj) and 2.04(min) (s each) (total: $2 \mathrm{H})$ and 2.55-2.67 (2H, m), $3.20(\mathrm{~d}, J 7 \mathrm{~Hz})(\mathrm{maj})$ and $3.27(\mathrm{~d}, J 7 \mathrm{~Hz})(\mathrm{min})$ (total: $2 \mathrm{H}), 5.57\left(\mathrm{dt}, J_{1} 11.6 \mathrm{~Hz}, J_{2} 7.2 \mathrm{~Hz}\right)$ (maj) and $5.81\left(\mathrm{dt}, J_{1} 15.2 \mathrm{~Hz}, J_{2} 7.2 \mathrm{~Hz}\right)(\mathrm{min})$ (total: $\left.1 \mathrm{H}\right), 5.95(\mathrm{~d}, J 11.6 \mathrm{~Hz})(\mathrm{maj})$ and $6.70(\mathrm{~d}, J 15.6 \mathrm{~Hz})(\mathrm{min})$ (total: $1 \mathrm{H}), 6.29(1 \mathrm{H}, \mathrm{br} \mathrm{s}), 7.24$ (maj) and $7.26(\mathrm{~min})$ (s each) (total: $1 \mathrm{H}), 7.25-7.38(1 \mathrm{H}, \mathrm{m}) \mathrm{ppm} .{ }^{13} \mathrm{C} \mathrm{NMR:} \delta$ 27.3, 27.4, 27.6, 28.1, 28.9, 29.3, 34.7, 34.9, 36.7, 36.8, 40.5, 40.8, 43.3, 45.0, 109.9, 110.7, 118.3, 119.5, $128.5,128.8,129.2,129.9,130.3,131.2,138.6,138.8,140.5,141.2,142.4,143.3$ ppm.

Protodebromination of (3+Z-Isomer). $n$-BuLi $(1.6 \mathrm{M}, 0.2 \mathrm{~mL}, 0.35 \mathrm{mmol})$ was added to the solution of the mixture of ( $3+Z$-isomer) $(0.075 \mathrm{~g}, 0.25 \mathrm{mmol})$ in THF $(1 \mathrm{~mL})$ at $-70^{\circ} \mathrm{C}$ under argon atmosphere. It was stirred at that temperature for about $2 \mathrm{~h}$, and the reaction mixture was quenched with water. THF was distilled off and the residual solution extracted with $\mathrm{Et}_{2} \mathrm{O}(3 \times 5 \mathrm{~mL})$. The combined organic layer was washed with water, dried and concentrated. The resulting crude product was purified by $\mathrm{CC}$ over $\mathrm{Al}_{2} \mathrm{O}_{3}$ to afford a mixture of 1 (Pleraplysillin-1) and its Z-isomer as light yellow oil in the PE eluate. Yield $40 \mathrm{mg}(77 \%) .{ }^{1} \mathrm{H} \mathrm{NMR} \mathrm{(500} \mathrm{MHz;}$ $\mathrm{CDCl}_{3}$ ): $\delta 0.88$ (min), 0.89 ( $\mathrm{min}$ ), 0.92 (maj) and 0.95 (maj) (s each; total: $6 \mathrm{H} ; 2 \times \mathrm{CH}_{3}$ ), 1.26-1.39 and 1.40-1.52 (m each) (total: $6 \mathrm{H} ; 3 \times \mathrm{CH}_{2}$ ), 1.89 (maj) and 1.91 ( $\mathrm{min}$ ) (s each; total: $1 \mathrm{H}$ ) and 3.19 (maj) and 3.36 (min) (d each, J 7.0/7.5 Hz) (total: $1 \mathrm{H}), 5.52-5.66$ and 5.76-5.86 (1H, m each), 5.94 (d, J $11.0 \mathrm{~Hz}$ (maj) and 6.13 (d, J 15.5 $\mathrm{Hz}$ ) (min) (total: $1 \mathrm{H}), 6.27$ (maj) and 6.29 ( $\mathrm{min}$ ) (br s each), (total: 1H), 7.22 (maj) and 7.23 (min) (s each) (total: 1H), $7.35(1 \mathrm{H}, \mathrm{m})$ ppm. ${ }^{13} \mathrm{C}$ NMR $\left(125 \mathrm{MHz} ; \mathrm{CDCl}_{3}\right): \delta$ 24.2, 24.4, 28.0, 28.1, 28.4, 28.6, 29.0, 29.2, 36.7, 36.9, 39.3, 39.8, 45.0, 47.5, 110.7, 110.8, 123.4, 125.1, 125.3, 126.2, 133.2, 133.3, 134.0, 134.2, 139.0, 139.3, 142.8, 142.9 ppm. HR-ESI(+)-MS: calcd for $\mathrm{C}_{15} \mathrm{H}_{21} \mathrm{O}[\mathrm{M}+\mathrm{H}]^{+}$217.1592, found 217.1602.

Note: For the ${ }^{1} \mathrm{H}$ NMR data of $(\mathbf{3}+Z$-isomer) and (1 + Z-isomer), "maj" refers to the major isomer (i.e., the Zisomer) and "min" refers to the minor isomer (i.e., the $E$-isomer).

\section{Acknowledgements}

Financial help from DST-SERB is acknowledged gratefully. Moumita Rakshit is thankful to the CSIR, Govt. of India for providing NET Junior and Senior Research Fellowships. 


\section{References}

1. Maiti, T. B.; Kar. G. K. Heterocycles 2009, 78, 3073-3080.

https://doi.org/10.3987/COM-09-11816

2. Pan, D., Kar, G. K., Ray, J. K., Lin, J. M., Amin, S., Chantrapromma, S., Fun, H. K. J. Chem. Soc., Perkin Trans. I 2001, 2470-2475.

https://doi.org/10.1039/b102750f

3. Ray, J. K., Gupta, S., Kar, G. K., Roy, B. C., Lin, J.-M., Amin, S. J. Org. Chem. 2000, 65, 8134-8138. https://doi.org/10.1021/jo005502+

4. Ray, J. K., Haldar, M. K., Gupta, S., Kar, G. K. Tetrahedron 2000, 56, 909-912. https://doi.org/10.1016/S0040-4020(99)01080-7

5. Rakshit, M.; Kar, G. K.; Chakrabarty, M. Monatsh. Chem.2015, 146, 1681-1688. https://doi.org/10.1007/s00706-015-1430-y

6. Shaik, F. H.; Kar, G. K. Beilstein J. Org. Chem. 2009, 5 (47), 1-7. https://doi.org/10.3762/bjoc.5.47

7. Cimino, G.; Stefano, S. D.; Minale, L.; Trivellone, E. Tetrahedron 1972, 28, 4761-4767. https://doi.org/10.1016/0040-4020(72)88084-0

8. Paul, V. J.; McConnell, O. J.; Fenical, W. J. Org. Chem. 1980, 45, 3401-3407. https://doi.org/10.1021/jo01305a006

9. Burreson, B. J.; Woolard, F. X.; Moore, R. E. Chem. Lett.1975, 1111-1114. https://doi.org/10.1246/cl.1975.1111

10. McConnell, O. J.; Fenical, W. J. Org. Chem.1978, 43, 4238-4241. https://doi.org/10.1021/jo00415a056

11. Masaki, Y.; Hashimoto, K.; Serizawa,Y.; Kaji, K. Chem. Lett. 1982, 1879-1880. https://doi.org/10.1246/cl.1982.1879

12. Masaki, Y.; Hashimoto, K.; Serizawa, Y.; Kaji, K. Bull. Chem. Soc. Jpn. 1984, 57, 3476-3482. https://doi.org/10.1246/bcsj.57.3476

13. Scott, W. J.; Crisp, G. T.; Stille, J. K. J. Am. Chem. Soc.1984, 106, 4630-4632. https://doi.org/10.1021/ja00328a063

14. Scott, W. J.; Stille, J. K. J. Am. Chem. Soc. 1986, 108, 3033-3040. https://doi.org/10.1021/ja00271a037

15. Samanta, K.; Kar, G. K.; Sarkar, A. K. Tetrahedron Lett.2008, 49, 1461-1464. https://doi.org/10.1016/i.tetlet.2008.01.010

16. Samanta, K. Ph. D. Thesis, Univ. Calcutta, Kolkata, India, 2011. 